\title{
Effect of irrigation and nitrogen fertilization on agronomic traits of sweet corn ${ }^{1}$
}

\author{
Epitácio José de Souza ${ }^{2}$, Fernando França da Cunha ${ }^{3}$, \\ Fernando Fagner Magalhães ${ }^{4}$, Thiago Ramos da Silva ${ }^{4}$, Osvaldir Feliciano dos Santos ${ }^{4}$
}

\section{ABSTRACT}

Irrigation and nitrogen fertilization are management practices that have positive results for the corn crop. This study aimed at evaluating the effect of nitrogen fertilization and irrigation on agronomic traits of sweet corn. Two experiments were carried out in two crop seasons (winter/spring and summer/autumn), in a split-plot design, with the main plots consisting of four irrigation levels $(50 \%, 75 \%, 100 \%$ and $125 \%$ of the crop evapotranspiration - ETc) and subplots consisting of four nitrogen doses $\left(0 \mathrm{~kg} \mathrm{ha}^{-1}, 100 \mathrm{~kg} \mathrm{ha}^{-1}\right.$, $200 \mathrm{~kg} \mathrm{ha}^{-1}$ and $300 \mathrm{~kg} \mathrm{ha}^{-1}$ ), applied at the V3 and V8 stages, via urea, in a randomized blocks design experiment, with four replications. Leaf nitrogen content, root depth, plant height, stem diameter, ear yield and water use efficiency were evaluated. In the winter/spring season, nitrogen fertilization did not affect yield, while in the summer/autumn season the dose that maximized yield was $300 \mathrm{~kg} \mathrm{ha}^{-1}$. Sweet corn showed better results when irrigated with replacements of $50 \%$ and $125 \%$ of ETc, respectively in the summer/autumn and winter/ spring seasons

KEY-WORDS: Zea mays var. Saccharata Sturt; drip irrigation; specialty corn; water use efficiency.

\section{INTRODUCTION}

Brazil is highlighted as a major corn producer, with a great potential for also producing sweet corn (Zea mays var. saccharata Sturt) (Ferreira et al. 2011). Sweet corn is quite popular in temperate countries, such as the United States, Canada and European nations, but not in Brazil (Borin et al. 2010). The lack of improved varieties and knowledge about cultivation techniques under

\section{RESUMO}

Efeito de irrigação e adubação nitrogenada nas características agronômicas de milho doce

A irrigação e a adubação nitrogenada são práticas de manejo que apresentam resultados positivos para a cultura do milho. Objetivou-se avaliar o efeito da adubação nitrogenada em cobertura e lâminas de irrigação sobre as características agronômicas de milho doce. Dois experimentos foram conduzidos em duas épocas de cultivo (inverno/primavera e verão/outono), em parcelas subdivididas, tendo-se nas parcelas quatro lâminas de irrigação $(50 \%, 75 \%, 100 \%$ e $125 \%$ da evapotranspiração da cultura - ETc) e nas subparcelas quatro doses de nitrogênio em cobertura ( $0 \mathrm{~kg} \mathrm{ha}^{-1}, 100 \mathrm{~kg} \mathrm{ha}^{-1}, 200 \mathrm{~kg} \mathrm{ha}^{-1}$ e $\left.300 \mathrm{~kg} \mathrm{ha}^{-1}\right)$, aplicadas nos estádios V3 e V8, via ureia, em delineamento em blocos casualizados, com quatro repetições. Foram avaliados o teor de nitrogênio foliar, profundidade de raízes, altura de planta, diâmetro de colmo, produtividade de espigas e eficiência do uso da água. No inverno/primavera, a adubação nitrogenada não afetou a produtividade, enquanto, no verão/outono, a dose que maximizou a produtividade foi de $300 \mathrm{~kg} \mathrm{ha}^{-1}$. O milho doce apresentou melhores resultados quando irrigado com reposições de $50 \%$ e $125 \%$ da ETc, respectivamente no verão/outono e inverno/primavera.

PALAVRAS-CHAVE: Zea mays var. Saccharata Sturt; irrigação por gotejamento; milhos especiais; eficiência do uso de água.

tropical conditions contribute to the low interest on sweet corn in Brazil.

The sweet corn crop cycle lasts from 90 to 100 days (Teixeira et al. 2009), allowing its production throughout the year (Zárate et al. 2009). It can be grown under a monocrop or intercrop system, and it is an alternative for small and medium farmers (Rocha et al. 2011). Almost all its production is destined for human consumption, either processed or in natura (Araújo et al. 1999, Pereira et al. 2009).

1. Manuscript received in Jan./2015 and accepted for publication in Aug./2015 (http://dx.doi.org/10.1590/1983-40632015v4533628).

2. Universidade Estadual Paulista “Júlio de Mesquita Filho" (Unesp), Departamento de Fitossanidade, Engenharia Rural e Solos, Ilha Solteira, SP, Brasil. E-mail: epitacio_jose@hotmail.com.

3. Universidade Federal de Viçosa (UFV), Departamento de Engenharia Agrícola, Viçosa, MG, Brasil. E-mail: dacunhaff@gmail.com. 4. Universidade Federal de Mato Grosso do Sul (UFMS), Chapadão do Sul, MS, Brasil. E-mails: magalhaes.fernandof@gmail.com, thiago.ramossilva10@gmail.com,osvaldir.feliciano@gmail.com. 
The instability of water regimes may restrict the development of corn crops, but the proper use of irrigation and nitrogen fertilization may improve yield and minimize risks during the production process (Borin et al. 2010).

A great amount of nitrogen is absorbed by sweet corn, and its availability affects yield (Okumura et al. 2011). This fact induces producers to use fertilizers in larger quantities, expecting to increase yield. However, Farinelli \& Lemos (2010) argue that the increase of nitrogen fertilizer doses reduces its efficiency and, as a result, the economic and environmental damages are increased. The increase of efficiency can be achieved by identifying the doses that maximize the fertilization effect.

This study aimed at evaluating the effect of irrigation and nitrogen fertilization on the agronomic traits of sweet corn grown in two crop seasons, in the northeast of Mato Grosso do Sul State, Brazil.

\section{MATERIAL AND METHODS}

The experiment was conducted at the Universidade Federal de Mato Grosso do Sul(UFMS), in Chapadão do Sul (1846'24'S, 52 37'25'W and $820 \mathrm{~m}$ of altitude), Mato Grosso do Sul State, Brazil. The climate is classified as humid tropical. Air temperature, relative humidity and rainfall averages, during the experimental period, are shown in Figure 1.

The soil of the experimental area was classified as clayish red-yellow Dystrophic Latosol (Oxisol), with density of $1.21 \mathrm{~g} \mathrm{~cm}^{-3}$, field capacity water content of $0.2632 \mathrm{dm}^{3} \mathrm{dm}^{-3}$ and plant permanent wilting point of $0.1887 \mathrm{dm}^{3} \mathrm{dm}^{-3}$. The soil chemical properties were evaluated before each harvest in laboratory (Table 1).

Two experiments with sweet corn were conducted in two distinct seasons: winter/spring (August 17th to November 24th, 2012) and summer/ autumn (March 3rd to May 31st, 2013).

The experiments were arranged in a split-plot randomized blocks design, with four replications, where irrigation regimes were the plots $(50 \%, 75 \%, 100 \%$ and $125 \%$ of the crop evapotranspiration - ETc) and nitrogen doses $\left(0 \mathrm{~kg} \mathrm{ha}^{-1}, 100 \mathrm{~kg} \mathrm{ha}^{-1}, 200 \mathrm{~kg} \mathrm{ha}^{-1}\right.$ and $\left.300 \mathrm{~kg} \mathrm{ha}^{-1}\right)$ the subplots. Experimental units consisted of $2.5 \mathrm{~m}$ long ( $0.5 \mathrm{~m}$ of border) and $4.8 \mathrm{~m}$ wide $(0.8 \mathrm{~m}$ of border)

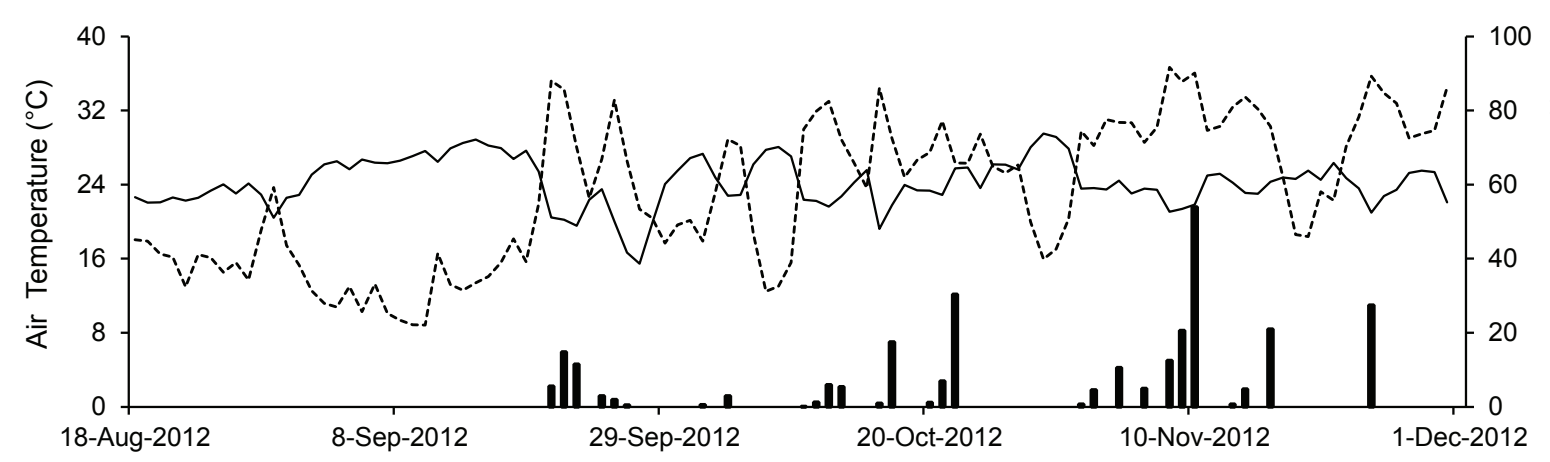

(a)

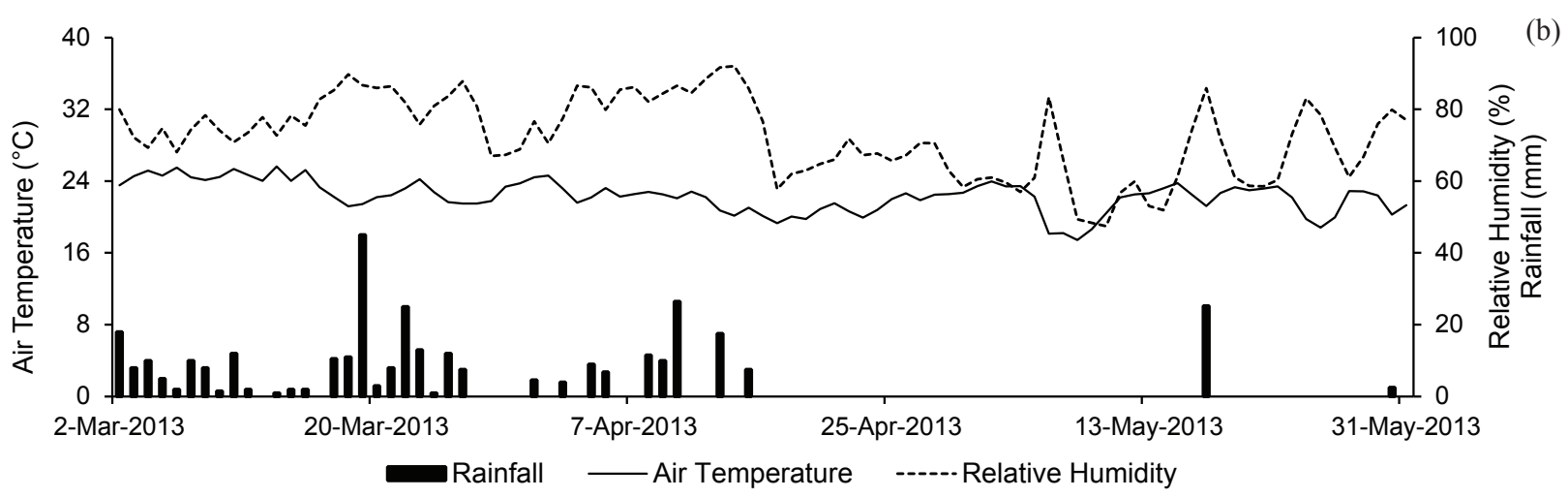

Figure 1. Daily variation of air temperature, relative humidity and rainfall in the winter/spring (a) and summer/autumn (b) crop seasons (Chapadão do Sul, Mato Grosso do Sul State, Brazil, 2012/2013). 
Table 1. Results for the soil chemical analysis of the experimental area at different crop seasons (Chapadão do Sul, Mato Grosso do Sul State, Brazil, 2012/2013).

\begin{tabular}{|c|c|c|c|c|c|c|c|c|c|c|c|}
\hline \multirow{2}{*}{ Season } & \multirow{2}{*}{$\begin{array}{c}\text { Layer } \\
\mathrm{cm}\end{array}$} & \multirow{2}{*}{$\begin{array}{c}\mathrm{pH} \\
\mathrm{CaCl}_{2}\end{array}$} & $\mathrm{Ca}+\mathrm{Mg}$ & $\mathrm{Ca}$ & \multicolumn{2}{|c|}{$\mathrm{Mg}$} & $\mathrm{Al}$ & $\mathrm{H}+\mathrm{Al}$ & K & K & $\mathrm{P}(\mathrm{Mel})$ \\
\hline & & & \multicolumn{7}{|c|}{$\longrightarrow \mathrm{cmol}_{\mathrm{c}} \mathrm{dm}^{-3}-$} & \multicolumn{2}{|c|}{$\mathrm{mg} \mathrm{dm} \mathrm{m}^{-3}$} \\
\hline \multirow{2}{*}{ Winter/spring } & $0-20$ & 5.3 & 4.20 & 3.30 & \multicolumn{2}{|c|}{0.90} & 0.08 & 4.9 & 0.29 & 113.0 & 13.8 \\
\hline & $20-40$ & 5.1 & 2.40 & 1.90 & \multicolumn{2}{|c|}{0.50} & 0.24 & 5.0 & 0.12 & 47.0 & 4.8 \\
\hline \multirow{2}{*}{ Summer/autumn } & $0-20$ & 4.8 & 4.40 & 3.40 & \multicolumn{2}{|c|}{1.00} & 0.09 & 4.8 & 0.13 & 52.0 & 4.8 \\
\hline & $20-40$ & 4.6 & 2.90 & 0.60 & \multicolumn{2}{|c|}{0.60} & 0.15 & 5.1 & 0.10 & 38.0 & 2.6 \\
\hline \multirow{2}{*}{ Season } & Layer & $\mathrm{S}$ & $\mathrm{B}$ & $\mathrm{Cu}$ & $\mathrm{Fe}$ & $\mathrm{Mn}$ & $\mathrm{Zn}$ & $\mathrm{OM}$ & & $\mathrm{EC}$ & $\mathrm{BS}$ \\
\hline & $\mathrm{cm}$ & \multicolumn{6}{|c|}{$-\mathrm{mg} \mathrm{dm}^{-3}-$} & $\mathrm{g} \mathrm{dm}^{-3}$ & \multicolumn{2}{|c|}{$\mathrm{cmol}_{\mathrm{c}} \mathrm{dm}^{-3}$} & $\%$ \\
\hline \multirow{2}{*}{ Winter/spring } & $0-20$ & 24.4 & 0.29 & 0.4 & 46.0 & 12.0 & 4.4 & 40.2 & & 9.4 & 47.8 \\
\hline & $20-40$ & 24.6 & 0.22 & 0.4 & 40.0 & 5.9 & 2.2 & 27.0 & & 7.5 & 33.5 \\
\hline \multirow{2}{*}{ Summer/autumn } & $0-20$ & 4.6 & 0.16 & 0.5 & 43.0 & 9.2 & 3.1 & 35.8 & & 9.3 & 48.6 \\
\hline & $20-40$ & 11.5 & 0.14 & 0.4 & 40.0 & 5.0 & 1.2 & 24.9 & & 8.1 & 37.0 \\
\hline
\end{tabular}

$\mathrm{OM}=$ organic matter; $\mathrm{CEC}=$ cation exchange capacity; $\mathrm{BS}=$ base saturation; $\mathrm{Mel}=$ Mehlich 1 method.

plots, resulting in a total area of $12.0 \mathrm{~m}^{2}$ and useful area of $8.0 \mathrm{~m}^{2}$.

The soil preparation consisted of plowing and harrowing. Soil acidity was corrected according to Sousa \& Lobato (2004) and fertilization at sowing was carried out based on soil chemical properties (Sousa \& Lobato 2004) (Table 1). Fertilization at sowing consisted of $60 \mathrm{~kg} \mathrm{ha}^{-1}$ of $\mathrm{P}_{2} \mathrm{O}_{5}, 60 \mathrm{~kg} \mathrm{ha}^{-1}$ of $\mathrm{K}_{2} \mathrm{O}$ and $30 \mathrm{~kg} \mathrm{ha}^{-1}$ of $\mathrm{N}$ for the first season (winter/ spring), and $120 \mathrm{~kg} \mathrm{ha}^{-1}$ of $\mathrm{P}_{2} \mathrm{O}_{5}, 60 \mathrm{~kg} \mathrm{ha}^{-1}$ of $\mathrm{K}_{2} \mathrm{O}$ and $30 \mathrm{~kg} \mathrm{ha}^{-1}$ of $\mathrm{N}$ for the second crop (summer/autumn). The nitrogen, phosphorus and potassium sources were respectively urea, single superphosphate and potassium chloride.

The sweet corn was sown on August 17th, 2012 (winter/spring), and February 03rd, 2013 (summer/autumn), spaced $80 \mathrm{~cm}$ between rows, with density of 75,000 seeds ha ${ }^{-1}$. The hybrid used was the Tropical Plus ${ }^{\circledR}$ (Syngenta), which has high yield potential, 90-110 days cycle, light yellow grain color, thin pericarp, sweet flavor and resistance to major diseases.

The sidedress nitrogen fertilization was divided and applied in the V3 and V8 phenological stages (Magalhães \& Durães 2006). The urea was applied in the plant rows, next to the drip tapes, which were turned on after fertilization to minimize volatilization losses. At V3, potassium fertilization was also applied at $80 \mathrm{~kg} \mathrm{ha}^{-1}$ of $\mathrm{K}_{2} \mathrm{O}$.

A drip irrigation system was used, with the following equation applied to calculate the actual irrigation required to treat $100 \%$ of the ETc:

$$
\mathrm{AIR}_{\mathrm{LOC}}=\sum_{\text {day } 1}^{\mathrm{i}} \mathrm{ET}_{0} \mathrm{~K}_{\mathrm{C}} \mathrm{K}_{\mathrm{S}} \mathrm{K}_{\mathrm{L}}-\mathrm{P}_{\mathrm{E}}
$$

where: $\mathrm{AIR}_{\mathrm{LOC}}=$ actual irrigation required in localized irrigation systems $(\mathrm{mm}) ; \mathrm{ET}_{0}=$ reference evapotranspiration $\left(\mathrm{mm} \mathrm{day}^{-1}\right) ; \mathrm{K}_{\mathrm{C}}=\mathrm{crop}$ coefficient (dimensionless); $\mathrm{K}_{\mathrm{S}}=$ soil moisture coefficient (dimensionless); $\mathrm{K}_{\mathrm{L}}=$ location coefficient (dimensionless); $\mathrm{P}_{\mathrm{E}}=$ effective rainfall in the period (mm).

The Penman-Monteith methodology was used to calculate the reference evapotranspiration $\left(\mathrm{ET}_{0}\right)$. Crop coefficients $\left(\mathrm{K}_{\mathrm{C}}\right)$ were 0.7 for the stage I (1st to 20th day after planting) and 1.1 for the stage III (51st day to harvest) (Bernardo et al. 2008). The $\mathrm{K}_{\mathrm{C}}$ daily values for the stage II (21st to 50th day) were obtained using the linear weighting between the values from the stages I and III. Soil moisture coefficients $\left(\mathrm{K}_{\mathrm{S}}\right)$ and location $\left(\mathrm{K}_{\mathrm{L}}\right)$ were established according to Bernardo et al. (2008).

The aboveground phenotypic evaluations were performed when the plants were at full male flowering. Ten plants were randomly sampled within the useful area of each plot. The evaluations were: a) leaf nitrogen content: the central third from ten opposite leaves below the ear were collected (Carmo et al. 2012) and evaluated according to Silva (2009); b) plant height: length $(\mathrm{cm})$ from the ground level to the highest leaf insertion point, using a tape measure (Carmo et al. 2012); c) stem diameter: diameter of the second internode (largest diameter), measured by a caliper (Carmo et al. 2012). 
The corn ears were harvested at the R3 phenological phase (November 24th, 2012, for the winter/spring, and May 31st, 2013, for the summer/ autumn), in the early morning hours (Kwiatkowski \& Clemente 2007).

The yield comprised all corn ears from the useful area of each experimental unit, which were subsequently weighed $\left(\mathrm{kg} \mathrm{plot}^{-1}\right)$, with values extrapolated to $\mathrm{tha}^{-1}$ (Carmo et al. 2012).

After harvest, longitudinal trenches were opened following the plant lines up to the last roots of the sweet corn, plus the excavation of $20 \mathrm{~cm}$ to confirm the absence of roots. Roots were measured $(\mathrm{cm})$ from the ground surface to the last root exposed, with a tape measure.

The water use efficiency was determined by the ratio between sweet corn yield and amount of water used in each treatment.

Data were submitted to regression analyzes, testing the linear and quadratic models. The models were chosen based on the significance of the regression coefficients ( $t$ test, at $5 \%$ ), coefficient of determination $\left(\mathrm{R}^{2}\right)$ and on the biological phenomenon. The program Sigmaplot v11.0 was used to perform the statistical analyses.

\section{RESULTS AND DISCUSSION}

Effective rainfall was higher for sweet corn in the winter/spring season (Table 2), due to the fact that rainfall was concentrated in periods when the crop presented higher values for crop $\left(\mathrm{K}_{\mathrm{C}}\right)$ and location $\left(\mathrm{K}_{\mathrm{L}}\right)$ coefficients (Figure 1).

The sweet corn grown in the winter/spring season (Table 2) showed higher water consumption because of two main reasons: a) greater water demand caused by higher daytime temperatures and lower air humidity (Figure 1), which coincided with the period when the sweet corn reached higher crop coefficient values; b) a longer crop life cycle during this season (99 days, whereas in the summer/autumn it was 90 days). Both crop cycles were within expectation: 90 to 100 days (Tan et al. 2009).

In both crop seasons irrigation regimes had a negative linear effect on leaf nitrogen content (Figure 2), probably due to the fact that sweet corn changes the carbon allocation to non-nitrogenous compounds, such as cellulose and lignin, rather than to proteins and amino acids. Chun et al. (2005) stated that the increase in carbon allocation from shoot to root formation, aiming at increasing surface area, results in a reduced nitrogen content in corn leaves. Franco et al. (2008) evaluated leaf nitrogen content of Urochloa decumbens, using two water levels ( $20 \%$ and $60 \%$ of the soil maximum water retention capacity), and observed an increase of $10.3 \%$ in nitrogen content in the lower water level treatment, when compared to the higher one.

The nitrogen content in the sweet corn cultivated in the summer/autumn season was not affected by the increase in nitrogen doses. Two possible reasons for this are: a) data variability resulted in a low value for the coefficient of determination, consequently affecting the adjustment of the regression equation; b) a proximity to the optimum point of leaf nitrogen content was reached for sweet corn in that season, hindering the response to the application of higher nitrogen doses. Nascimento et al. (2012) report that the adequate nitrogen content for corn crop ranges from $2.7 \%$ to $3.5 \%$.

In the winter/spring season, nitrogen doses were responsible for a quadratic effect on leaf nitrogen content (Figure 2). The nitrogen fertilization dose that maximized the leaf nitrogen content was $185.6 \mathrm{~kg} \mathrm{ha}^{-1}$. The reduction in leaf nitrogen content after this dose may be due to the fact that the use of nitrogen decreases as the doses applied increase, for exceeding the crop needs

Table 2. Effective rainfall, actual irrigation required and total water depth applied in each treatment and crop season (Chapadão do Sul, Mato Grosso do Sul State, Brazil, 2012/2013).

\begin{tabular}{llrrrr}
\hline \multirow{2}{*}{ Season } & \multicolumn{1}{c}{ Event } & \multicolumn{4}{c}{ Irrigation regime } \\
\cline { 3 - 6 } & & $50 \%$ ETc & $75 \%$ ETc & $100 \%$ ETc & $125 \%$ ETc \\
\hline \multirow{3}{*}{ Winter/spring } & Effective rainfall (mm) & 258.8 & 220.6 & 185.1 & 185.1 \\
& Actual irrigation required $(\mathrm{mm})$ & 111.3 & 167.0 & 222.7 & 278.4 \\
& Total water depth $(\mathrm{mm})$ & 370.1 & 387.7 & 407.8 & 463.4 \\
\hline \multirow{3}{*}{ Summer/autumn } & Effective rainfall $(\mathrm{mm})$ & 213.7 & 208.6 & 196.2 & 196.2 \\
& Actual irrigation required $(\mathrm{mm})$ & 64.5 & 96.8 & 129.1 & 161.3 \\
& Total water depth $(\mathrm{mm})$ & 278.3 & 305.4 & 325.3 & 357.6 \\
\hline
\end{tabular}




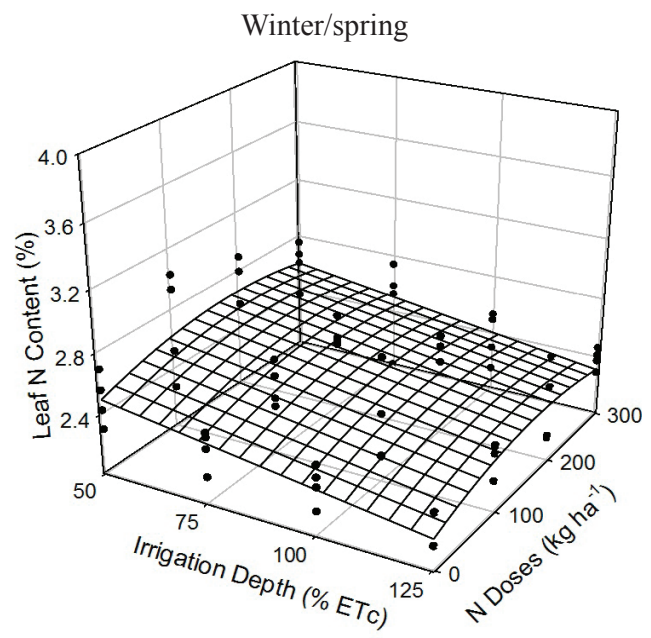

$\mathrm{LNC}=2.7 \mathrm{E}+0 * *-3.9 \mathrm{E}-3 * * \mathrm{ID}+1.8 \mathrm{E}-3^{*} \mathrm{ND}-4.9 \mathrm{E}-6^{*} \mathrm{ND}^{2}$ $\mathrm{R}^{2}=0.8750 \quad \mathrm{p}<0.0001$

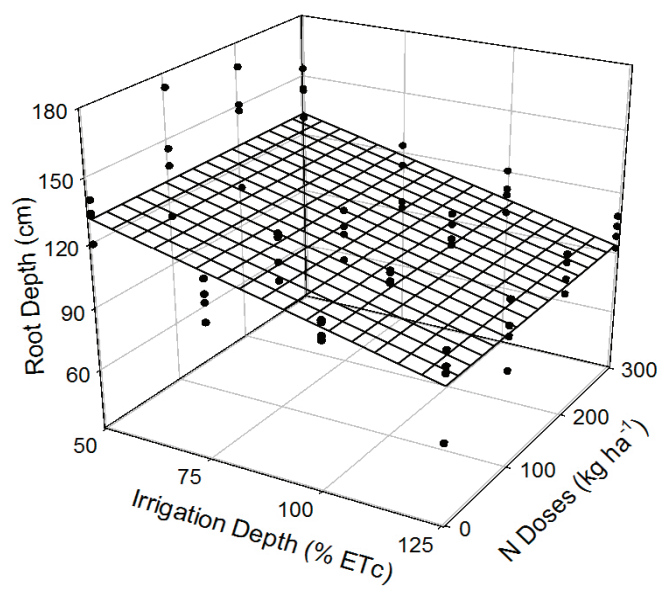

$\mathrm{RD}=1.6 \mathrm{E}+2 * *-4.9 \mathrm{E}-1 * * \mathrm{ID}$

$\mathrm{R}^{2}=0.6278 \quad \mathrm{p}<0.0001$

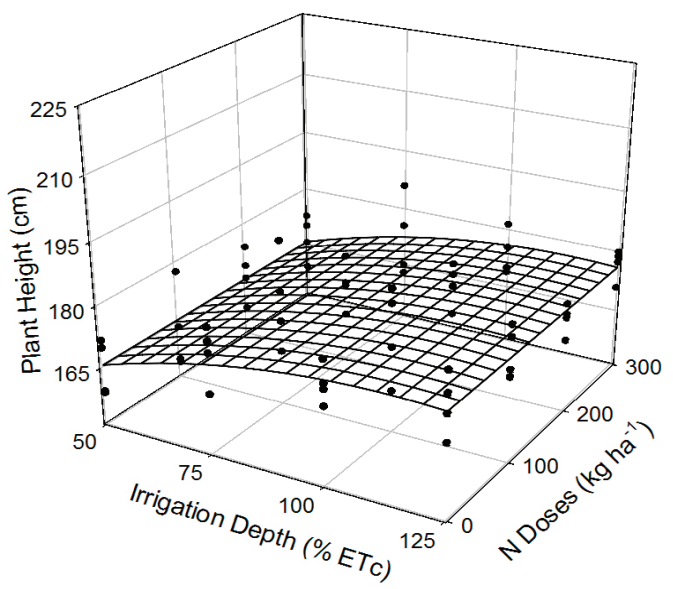

$\mathrm{PH}=1.4 \mathrm{E}+2 * *+6.2 \mathrm{E}-1 * \mathrm{ID}-2.8 \mathrm{E}-3 * \mathrm{ID}^{2}$

$\mathrm{R}^{2}=0.8435 \quad \mathrm{p}<0.0001$

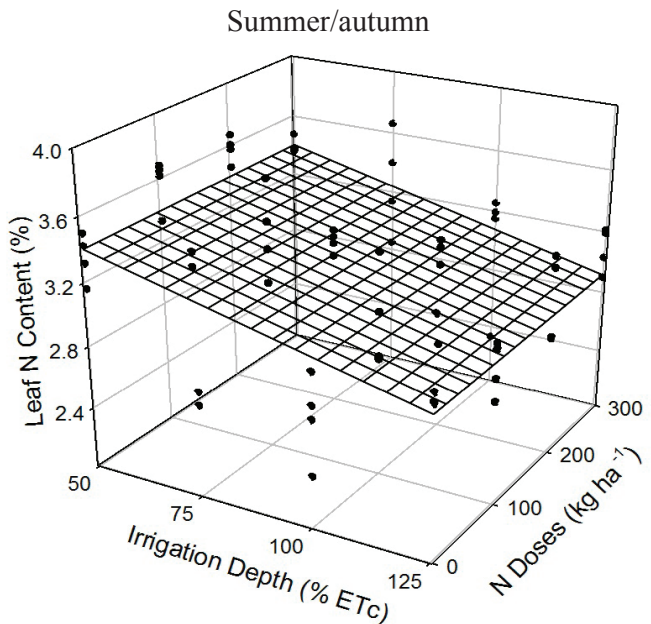

$\mathrm{LNC}=3.7 \mathrm{E}+0 * *-6.5 \mathrm{E}-3 * * \mathrm{ID}$

$\mathrm{R}^{2}=0.5807 \quad \mathrm{p}<0.0001$

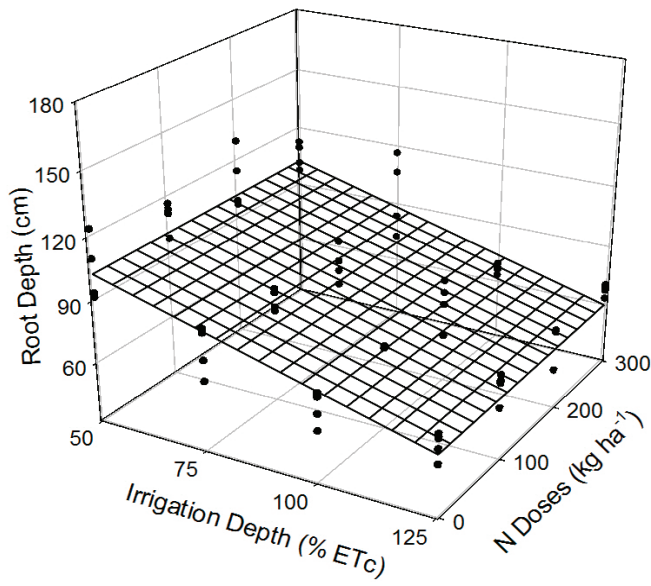

$\mathrm{RD}=1.3 \mathrm{E}+2 * *-5.7 \mathrm{E}-1 * * \mathrm{ID}$

$\mathrm{R}^{2}=0.8508 \quad \mathrm{p}<0.0001$

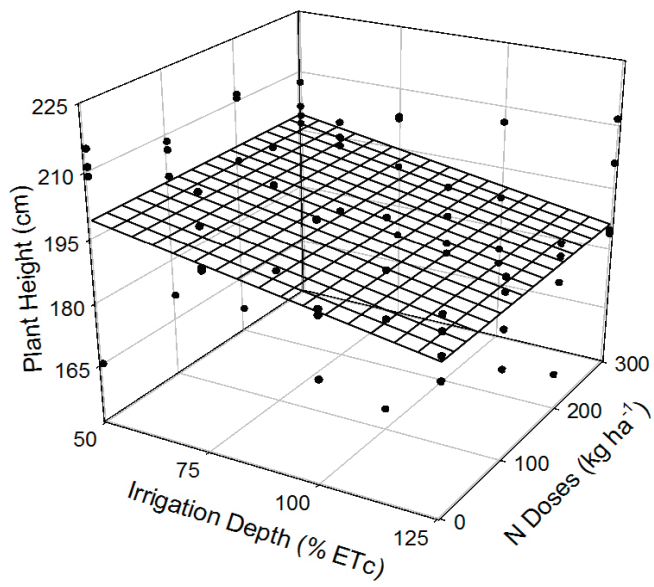

$\mathrm{PH}=2.1 \mathrm{E}+2 * *-1.7 \mathrm{E}-1 * * \mathrm{ID}$

$\mathrm{R}^{2}=0.4686 \quad \mathrm{p}=0.0075$

Figure 2. Estimated leaf nitrogen content (LNC), root depth (RD) and plant height (PH), concerning irrigation depths (ID) and nitrogen doses (ND), in different crop seasons (Chapadão do Sul, Mato Grosso do Sul State, Brazil, 2012/2013). * p <0.05; $* * \mathrm{p}<0.01$. 
(Fernandes \& Buzetti 2005). The unused nitrogen can be lost as ammonia.

Regardless of crop season, the irrigation regimes had a negative linear effect on the depth of sweet corn roots (Figure 2). In treatments with lower water depths, probably plants deepened their roots, in order to search for water at deeper soil layers. Schlichting et al. (2015) also observed this trend in the growth of corn roots as a defense to water stress conditions.

The nitrogen doses had no effect on the depth of sweet corn roots (Figure 2). Soares et al. (2009) also found no difference for root depth in six corn cultivars, applying two nitrogen doses (zero and $6 \mathrm{mmol} \mathrm{L}^{-1}$ of soil) in a Red Latosol. According to these authors, high nitrate concentrations can even reduce root growth, since this element inhibits the auxin flow to the roots.

The irrigation regimes had a quadratic effect on plant height in the winter/spring season (Figure 2). According to the regression equation, the water depth that maximized plant height was $111.3 \%$ of ETc, with plants reaching $1.77 \mathrm{~m}$. In the summer/autumn season, this effect was linear negative. Regardless of crop season, the nitrogen doses had no effect on plant height (Figure 2), as also observed by Valderrama et al. (2011). According to these authors, the crop response depends on the cropping history of the area, on weather conditions and nitrogen fertilization. The cultivar and plant density also influence this effect.

On the other hand, some studies have shown positive response in plant height with nitrogen fertilization (Silva et al. 2006, Khazaei et al. 2010, Pereira Júnior et al. 2012). The lack of response in this study may have occurred because the nitrogen availability in the soil was already at optimum levels for the crop. This hypothesis is supported by the lack of response on leaf nitrogen content (Figure 2).

The irrigation regimes had a quadratic effect on stem diameter, in the summer/autumn season (Figure 3). According to the regression equation, the water depth that maximized the stem diameter was $83.0 \%$ of the ETc, resulting in a stem of $19.89 \mathrm{~mm}$. According to Calonego et al. (2011), the increase in plant height reduces the stem diameter, partly agreeing with the results in this study, as observed in the summer/autumn season (Figures 2 and 3). Regardless of crop season, the nitrogen fertilization had no effect on stem diameter (Figure 3).
The irrigation regimes had a positive linear effect on ear yield, in the winter/spring season (Figure 3), showing that there was water restriction in treatments with lower water depths. This result suggests an irrigation regime of $125 \%$ of the ETc for the winter/spring season.

In the summer/autumn season, the irrigation regimes had a negative linear effect on ear yield (Figure 3). Therefore, an irrigation regime of $50 \%$ of the ETc is suggested in this season, in order to ensure higher yield and lower water and electricity loss. This response was not expected, but may be explained by the fact that rainfall in this crop season was concentrated at the beginning of the cycle. Therefore, treatments that received lower water depths had no water restrictions, and treatments with larger water depths had moisture contents near to field capacity, preceding rainfall, resulting in higher water percolation and possibly nutrient lixiviation.

Another possible explanation is based on the root system performance (Figure 2). The increase in irrigation reduced the roots' depth, and consequently the soil volume explored by them, possibly decreasing the nutrients input by the sweet corn. This hypothesis has support on the lower leaf nitrogen content with increasing irrigation (Figure 2). The same effect was also observed in the winter/spring season, although in a milder way, as observed in the regression coefficients (Figure 2). According to the equations in Figure 2, the root depths in treatments irrigated with $125 \%$ of the ETc were $60 \mathrm{~cm}$ in the summer/autumn season and $95 \mathrm{~cm}$ in the winter/spring.

Heinemann et al. (2009), evaluating common corn in different locations in the Goiás State, Brazil, concluded that water deficit stress is not the main impediment to the development of corn crops in normal seasons. The actual concern occurs in soils that hinder root development by physical, chemical or biological factors.

The nitrogen doses had a positive linear effect on ear yield, in the summer/autumn season (Figure 3). According to Okumura et al. (2011), the increase of nitrogen doses increases the composition of amino acid, protein, chlorophyll and other essential enzymes that stimulate the sweet corn growth and development. The nitrogen response was related to the irrigation regimes, since the nitrogen fertilization increased yield in treatments with lower water depths. The highest yield was $20.4 \mathrm{Mg} \mathrm{ha}^{-1}$, according to the regression equation, obtained with an irrigation 


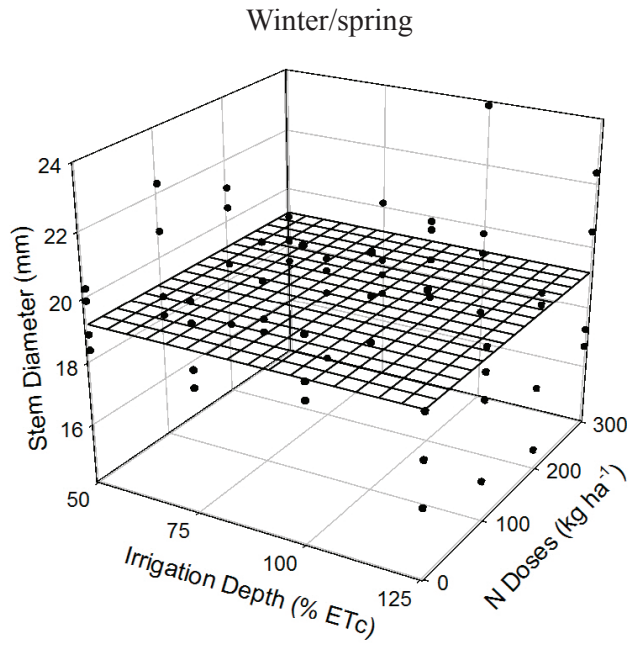

$\mathrm{SD}=1.9 \mathrm{E}+1$

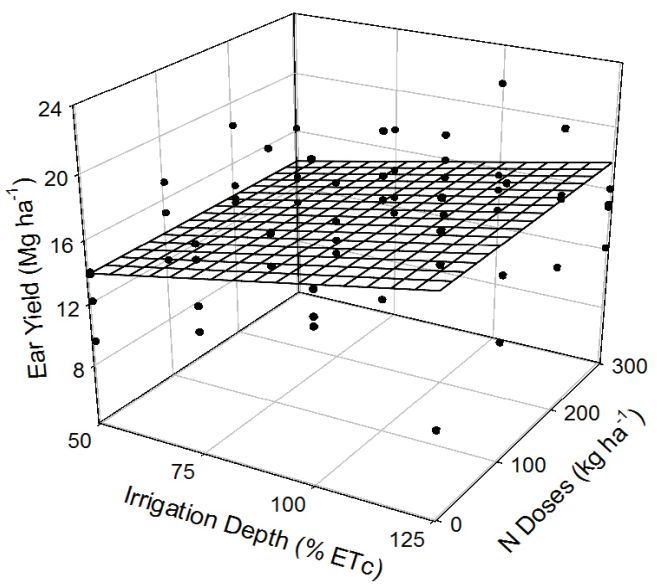

$\mathrm{EY}=1.1 \mathrm{E}+1 * *+5.1 \mathrm{E}-2 * * \mathrm{ID}$

$\mathrm{R}^{2}=0.6334 \quad \mathrm{p}=0.0010$

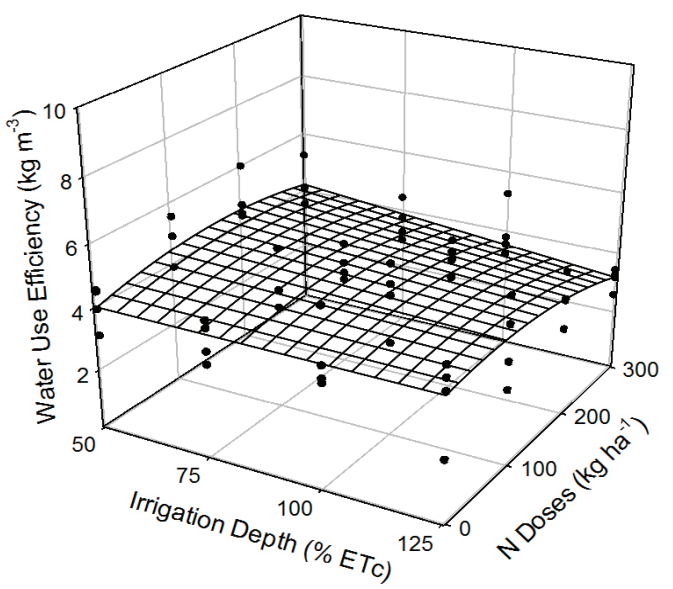

$\mathrm{WUE}=4.0 \mathrm{E}+0 * *+9.4 \mathrm{E}-3 * \mathrm{ND}-4.6 \mathrm{E}-5^{*} \mathrm{IDND}-2.1 \mathrm{E}-5^{*} \mathrm{ND}^{2}$ $\mathrm{R}^{2}=0.4993 \quad \mathrm{p}<0.0196$
Summer/autumn

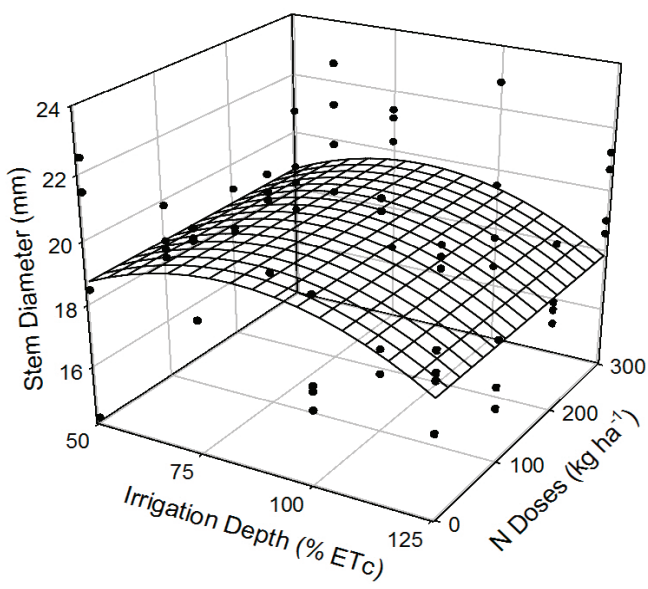

$\mathrm{SD}=1.3 \mathrm{E}+1 * *+1.7 \mathrm{E}-1 * \mathrm{ID}-1.0 \mathrm{E}-3 * \mathrm{ID}^{2}$ $\mathrm{R}^{2}=0.2983 \quad \mathrm{p}=0.0230$

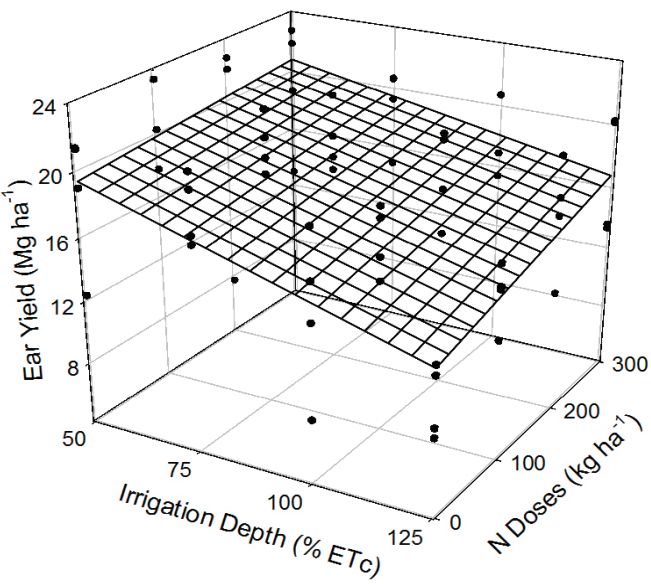

$\mathrm{EY}=2.4 \mathrm{E}+1 * *-8.3 \mathrm{E}-2 * * \mathrm{ID}+9.5 \mathrm{E}-5 * \mathrm{ID} \mathrm{ND}$ $\mathrm{R}^{2}=0.8192 \quad \mathrm{p}<0.0001$

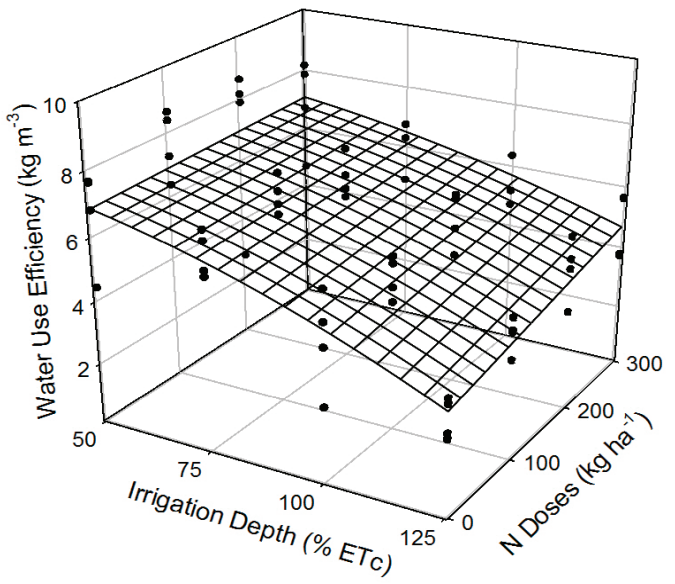

$\mathrm{WUE}=7.6 \mathrm{E}+0 * *-3.0 \mathrm{E}-4 * \mathrm{ID}^{2}+2.9 \mathrm{E}-7 * \mathrm{ID}^{2} \mathrm{ND}$ $\mathrm{R}^{2}=0.9240 \quad \mathrm{p}<0.0001$

Figure 3. Estimate stem diameter (SD), corn ear yield (EY) and water use efficiency (WUE), according to irrigation depths (ID) and nitrogen doses (ND), in different crop seasons (Chapadão do Sul, Mato Grosso do Sul State, Brazil, 2012/2013). $* \mathrm{p}<0.05 ; * \mathrm{p}<0.01$ 
regime of $50 \%$ of the ETc and nitrogen fertilization of $300 \mathrm{~kg} \mathrm{ha}^{-1}$. This value exceeds the highest yield (19.5 $\mathrm{Mg} \mathrm{ha}^{-1}$ ) found by Carmo et al. (2012), applying $150 \mathrm{~kg} \mathrm{ha}^{-1}$ of nitrogen in a summer crop in Palmeiras, Goiás State, Brazil. In the winter/spring season, nitrogen doses did not increase yield (Figure 3), agreeing with Aguiar et al. (2012), which applied nitrogen doses from 0 to $144 \mathrm{~kg} \mathrm{ha}^{-1}$ to sweet corn grown in Gurupi, Tocantins State, Brazil.

The effect of nitrogen doses was lower than expected for some parameters, probably due to inadequate potassium levels or to the interaction between absorption and use of these two macronutrients (Costa et al. 2008). The reduction of potassium contents in the soil (Table 1) between the two crop seasons, and the fact that the potassium supplementation was not proportional to the nitrogen doses, in order to balance the interaction between these two elements, reinforces this hypothesis. This interaction is related to the activity of the nitrate reductase enzyme, which acts in the inorganic nitrogen incorporation (Silva et al. 2011).

Researches applying sidedress fertilization in corn at the V4 and V6 stages reached positive results (Repke et al. 2013, Rotili et al. 2014). Therefore, the methodology used in the present research, applying nitrogen at the V 3 and V8 stages, suggests that the sidedress fertilization occurred too early or too late, influencing the effect of the nitrogen doses in the evaluated parameters. Thus, new researches should be developed to study this hypothesis.

The water use efficiency decreased as the water depth increased (Figure 3). This was already expected, since these factors are inversely proportional. In the summer/autumn season, the reduction in water use efficiency was higher also due to the reduced ear yield. In the winter/spring season, nitrogen fertilization had a quadratic effect on water use efficiency. According to the regression equation, the nitrogen dose that maximized this parameter was $168.4 \mathrm{~kg} \mathrm{ha}^{1}$ (Figure 3). Nitrogen doses in the summer/autumn season had a positive linear effect on water use efficiency.

\section{CONCLUSIONS}

1. Sweet corn showed better results when irrigated with $125 \%$ of the ETc in the winter/spring crop season and $50 \%$ of the ETc in the summer/ autumn.
2. In the winter/spring crop season nitrogen fertilization did not affect yield, while in the summer/autumn the nitrogen dose that maximized the sweet corn yield was $300 \mathrm{~kg} \mathrm{ha}^{-1}$.

\section{REFERENCES}

AGUIAR, C. B. N. et al. Desempenho agronômico de híbridos de milho verde em função da adubação nitrogenada de cobertura. Revista Ciências Agrárias, Belém, v. 55, n. 1, p. 11-16, 2012.

ARAÚJO, W. F.; SAMPAIO, R. A.; MEDEIROS, R. D. Irrigation and nitrogen fertilization of corn. Scientia Agricola, Piracicaba, v. 56, n. 4, p. 909-914, 1999.

BERNARDO, S.; SOARES, A. A.; MANTOVANI, E. C. Manual de irrigação. 8. ed. Viçosa: UFV, 2008.

BORIN, A. L. D. C.; LANA, R. M. Q.; PEREIRA, H. S. Absorção, acúmulo e exportação de macronutrientes no milho doce cultivado em condições de campo. Ciência e Agrotecnologia, Lavras, v. 34, ed. esp., p. 1591-1597, 2010.

CALONEGO, J. C. et al. Produtividade e crescimento de milho em diferentes arranjos de plantas. Agrarian, Dourados, v. 4, n. 12, p. 84-90, 2011.

CARMO, M. S. et al. Doses e fontes de nitrogênio no desenvolvimento e produtividade da cultura de milho doce (Zea mays convar. saccharata var. rugosa). Bioscience Journal, Uberlândia, v. 28, supl. 1, p. 223-231, 2012.

CHUN, L. et al. Genetic analysis of corn root characteristics in response to low nitrogen stress. Plant and Soil, Dordrecht, v. 276, n. 2, p. 369-382, 2005.

COSTA, K. A. P. et al. Extração de macronutrientes pela fitomassa do capim-xaraés em função de doses de nitrogênio e potássio. Ciência Rural, Santa Maria, v. 38, n. 4, p. 1162-1166, 2008.

FARINELLI, R.; LEMOS, L. B. Produtividade e eficiência agronômica do milho em função da adubação nitrogenada e manejos de solo. Revista Brasileira de Milho e Sorgo, Sete Lagoas, v. 9, n. 2, p. 135-146, 2010.

FERNANDES, F. C. S.; BUZETTI, S. Efeito de níveis de nitrogênio na produtividade de seis cultivares de milho (Zea mays L.). Revista Científica Eletrônica de Agronomia, Garça, v. 7, n. 1, p. 1-7, 2005.

FERREIRA, M. G. et al. Aspectos químicos e físicos dos grãos de milho doce sob estresse hídrico. Revista Brasileira de Agrotecnologia, Pombal, v. 1, n. 1, p. 1-6, 2011.

FRANCO, H. C. J. et al. Perda de nitrogênio pela Brachiaria decumbens após a antese: relação com a 
umidade do solo. Ciência Rural, Santa Maria, v. 38, n. 1, p. 96-102, 2008.

HEINEMANN, A. B. et al. Padrões de deficiência hídrica para a cultura de milho (safra normal e safrinha) no Estado de Goiás e suas consequências para o melhoramento genético. Ciência e Agrotecnologia, Lavras, v. 33, n. 4, p. 1026-1033, 2009.

KHAZAEI, F. et al. Study of the correlation, regression and path coefficient analysis in sweet corn (Zea mays var. Saccharata) under different levels of plant density and nitrogen rate. Journal of Agricultural and Biological Science, Guangxi, v. 5, n. 6, p. 14-10, 2010.

KWIATKOWSKI, A.; CLEMENTE, E. Características do milho doce (Zea mays L.) para industrialização. Revista Brasileira Agroindustrial, Ponta Grossa, v. 1, n. 2, p. 93103, 2007.

MAGALHÃES, P. C.; DURÃES, F. O. M. Fisiologia da produção do milho. Sete Lagoas: MAPA, 2006.

NASCIMENTO, F. M. et al. Diagnose foliar em plantas de milho em sistema de semeadura direta em função de doses e épocas de aplicação de nitrogênio. Revista Brasileira de Tecnologia Aplicada nas Ciências Agrárias, Guarapuava, v. 5, n. 1, p. 67-86, 2012.

OKUMURA, R. S.; MARIANO, D. C.; ZACCHEO, P. V. C. Uso de fertilizante nitrogenado na cultura do milho. Pesquisa Aplicada \& Agrotecnologia, Pombal, v. 4, n. 2, p. 226-244, 2011.

PAULINO, J. et al. Situação da agricultura irrigada no Brasil de acordo com o censo agropecuário 2006. Irriga, Botucatu, v. 16, n. 2, p. 163-176, 2011.

PEREIRA JÚNIOR, E. B. P. et al. Produção e qualidade de milho-verde com diferentes fontes e doses de adubos orgânicos. Revista Verde de Agroecologia e Desenvolvimento Sustentável, Mossoró, v. 7, n. 2, p. 277282, 2012.

PEREIRA, A. F. et al. Caracteres agronômicos e nutricionais de genótipos de milho doce. Bioscience Journal, Uberlândia, v. 25, n. 1, p. 104-112, 2009.

REPKE, R. A. et al. Eficiência da Azospirillum brasilense combinada com doses de nitrogênio no desenvolvimento de plantas de milho. Revista Brasileira de Milho e Sorgo, Sete Lagoas, v. 12, n. 3, p. 214-226, 2013.
ROCHA, D. R.; FORNASIER FILHO, D.; BARBOSA, J. C. Efeitos da densidade de plantas no rendimento comercial de espigas verdes de cultivares de milho. Horticultura Brasileira, Brasília, DF, v. 29, n. 3, p. 392$397,2011$.

ROTILI, E. A. et al. Rentabilidade de diferentes híbridos de milho, no Estado do Tocantins, safra 2009/2010. Journal of Biotechnology and Biodiversity, Gurupi, v. 5, n. 2, p. 162-167, 2014.

SCHLICHTING, A. F. et al. Characteristics of corn production irrigation and time-varying doses of nitrogen. African Journal of Agricultural Research, Lagos, v. 10, n. 8, p. 821-828, 2015.

SILVA, D. A. et al. Culturas antecessoras e adubação nitrogenada na cultura do milho, em sistema plantio direto. Revista Brasileira de Milho e Sorgo, Sete Lagoas, v. 5, n. 1, p. 75-88, 2006.

SILVA, F. C. Manual de análises químicas de solos, plantas e fertilizantes. 2. ed. Brasília, DF: Embrapa Informação Tecnológica, 2009.

SILVA, S. M. et al. Atividade da enzima nitrato redutase em milho cultivado sob diferentes níveis de adubação nitrogenada e potássica. Ciência Rural, Santa Maria, v. 41, n. 11, p. 1931-1937, 2011.

SOARES, M. O. et al. Discriminação de linhagens de milho quanto à utilização de nitrogênio, por meio da avaliação de características do sistema radicular. Revista Brasileira de Milho e Sorgo, Sete Lagoas, v. 8, n. 1, p. 95 105, 2009.

SOUSA, D. M. G.; LOBATO, E. Cerrado: correção do solo e adubação. 2. ed. Brasília, DF: Embrapa Informação Tecnológica, 2004.

TEIXEIRA, F. F. et al. Aspectos agronômicos e de qualidade de espiga em famílias endogâmicas de milho doce. Sete Lagoas: Embrapa Milho e Sorgo, 2009.

VALDERRAMA, M. et al. Fontes e doses de NPK em milho irrigado sob plantio direto. Pesquisa Agropecuária Tropical, Goiânia, v. 41, n. 2, p. 254-263, 2011.

ZÁRATE, N. A. H. et al. Produção e renda líquida de milho verde em função da época de amontoa. Semina: Ciências Agrárias, Londrina, v. 30, n. 1, p. 95-100, 2009. 